Transport

Volume 165 Issue TR2

Traffic uncertainty in toll motorway

concessions in Spain

Baeza and Vassallo
Proceedings of the Institution of Civil Engineers

Transport 165 May 2012 Issue TR2

Pages 97-105 http://dx.doi.org/10.1680/tran.2012.165.2.97

Paper $\mathbf{8 0 0 0 1 0}$

Received 12/02/2008 Accepted 22/10/2010

Keywords: economics \& finance/risk analysis/roads \& highways

\title{
Traffic uncertainty in toll motorway concessions in Spain
}

María A. Baeza PhD

Lecturer, Financial Economics Department, University of Granada, Spain
José M. Vassallo PhD

Associate Professor, Transport Department, Universidad Politécnica de Madrid, Spain

This study assessed the inaccuracy of the traffic estimates for toll motorway concessions in Spain. It was found that the estimates conducted by both the government and the concessionaire showed a significant bias towards overestimating traffic. The level of overestimation in Spain is even greater than that reported by other studies based on worldwide data. The notorious levels of overestimation entail severe burdens to the economics of the concessionaires that often prompt renegotiations of the contracts, which are often accepted by the government. These renegotiations usually end up with toll changes or extension of the concession terms, which have to be ultimately borne by future motorway users. It is postulated herein that the bias towards overestimating traffic in toll motorways in Spain is mostly caused by strategic issues rather than by modelling errors.

\section{Introduction}

Many governments are implementing new ways to encourage private participation in constructing, financing, and operating transport infrastructure. Public-private partnerships (PPPs) are mostly implemented to circumvent budgetary constraints, and encourage efficiency and quality in the provision of public infrastructure (OECD, 2008). The latter objective is achieved through the integration of the life cycle of the project including the design, construction, financing and operation phases.

One of the most common ways to boost private participation in infrastructure projects is through the concession system, which consists basically of transferring construction, maintenance, and operation of the infrastructure to a private consortium, in exchange for which that consortium receives the right to charge a user fee, for a period of time, fixed or variable, as contractually agreed upon in advance (Vassallo, 2004). Concession contracts have a long tradition in some countries, such as the United Kingdom (Debande, 2005), Spain (Izquierdo and Vassallo, 2004), France (Fayard and Bousquet, 1998), Chile (Gómez-Lobo and Hinojosa, 2000) and Mexico (Guasch et al., 2003). Presently, the United States is testing the concession contract model to manage transport infrastructure and monetise valuable transport assets (Foote, 2006).

Concession contracts have to deal with many risks, such as construction, land acquisition, maintenance and operation, legal, political and so on (Flyvbjerg et al., 2003). Traffic risk transpired to be one of the most important risks as well as most difficult to manage. Although road traffic inaccuracy has been analysed in several studies (Bain, 2009; Bain and Plantagie, 2004; Bain and Polakovic, 2005; Flyvbjerg et al., 2005), these studies put together in the same sample different kind of roads and motorways placed in different countries, which are granted and regulated under very different approaches.
The aims of this study were threefold: first, to characterise the level of accuracy of actual traffic compared to the initial estimates made by both the government and the concessionaire for toll motorway concessions in Spain; second, to attempt to explain the reasons that might explain such deviations and the significant bias towards overestimation; and finally, to identify the consequences that the deviations may have for social welfare.

In Section 2 the research published to date is assessed regarding the accuracy of traffic estimates, specifically for toll roads, and the different causes of errors are explained. In Section 3 an overview of the main characteristics of concession contracts in Spain is given. In Section 4 a detailed analysis of the inaccuracy of the traffic estimates for toll motorways in Spain is conducted, and the reasons for this inaccuracy and its repercussions for social welfare are evaluated. Section 5 includes the final conclusions of the research.

\section{Accuracy of traffic estimates for toll roads: research to date}

\subsection{Studies conducted up to the present}

The empirical results to date have demonstrated how forecasting traffic in toll roads shows a consistent bias towards overestimation. A study conducted in 2005 by Standard \& Poor's (S\&P), whose aggregated results are summarised by Bain (2009), assessed the accuracy of traffic forecasts using a worldwide database including over 100 toll roads. The forecasts used in this study to compare real with predicted traffic are those embedded in the models used at the financial close so these forecasts have been approved by the banks.

This study revealed that on average forecasters overestimate firstyear traffic by $23 \%$. Beyond the first year, it showed that optimism bias and error measurement statistics remained constant 
through years 2 to 5 (Bain and Polakovic, 2005). Moreover, traffic forecast errors for toll motorways seemed to be consistently in a range between 0.20 and 0.30 in terms of standard deviation. The study also showed that the overestimation level seems to be greater in jurisdictions with a short history of toll roads than in those with a long history.

Flyvbjerg et al. (2005) carried out a large study comparing real traffic with forecasts for 214 road projects in 14 countries - most of which were free roads. Unlike the S\&P study, this study showed almost no overestimation bias, even though they reported forecasting errors (standard deviation $=0.44$ ) even greater than the S\&P study. The difference between these two studies may be based on the different nature of the roads. The study by Flyvbjerg et al. (2005) focused mainly on free roads on which traffic estimations were mostly conducted by the public sector. However, the study by Standard \& Poor's (Bain and Polakovic, 2005) focused its sample on motorway concessions where bidders calculate their own estimates.

A comparison between the two studies mentioned above shows that the average overestimation bias varied substantially between estimates conducted by the government for free roads, where no average overestimation was reported, and estimates conducted by the private sector for toll roads, where a significant level of overestimation was noted.

\subsection{Reasons for the errors in the estimates}

Two different kinds of errors can be identified in the traffic estimates (Vassallo and Baeza, 2007): 'forecasting errors' and 'strategic errors'. Forecasting errors show the inability of the forecaster to exactly predict the future traffic because of the imperfection of the models or the uncertainty of the endogenous variables. Strategic errors, however, show the bias intentionally introduced by the forecaster in order to have a greater chance of reaching its objectives.

De Jong et al. (2007) conducted an interesting study aimed at determining the reasons for 'forecasting errors' in traffic estimates. They claim that these errors are caused by input uncertainty and model uncertainty. Input uncertainty refers to the difficulty of accurately knowing the value of the inputs that determine traffic forecasts. From an analysis conducted in a case study in the Netherlands, they concluded that the contribution of input uncertainty to the bulk of the 'forecasting errors' was generally much larger than that of model uncertainty.

Strategic errors mostly depend on the incentives that the stakeholder in charge of the forecasts has to reach its goals. The literature shows several reasons which might explain strategic errors. One of the reasons is the so-called winner's curse (Capen et al., 2001), which means that the bidders tend to make overoptimistic offers to win the concession contract at all costs. The winner's curse effect is accentuated in institutional frameworks in which renegotiation is easier (Athias and Nuñez, 2008).
Consequently, it seems that the willingness to renegotiate by the government is crucial for the bidders in their decision to commit strategic errors.

The public authorities in charge of the project might also have incentives to inflate their traffic forecasts for several reasons: for instance, to justify the construction of a project whose feasibility is actually doubtful from a social point of view (usually called 'white elephant'); or to convince the Treasury Department that no public contributions are necessary to make the project financially viable for the private sector.

\section{Motorway concessions in Spain: an overview}

\subsection{Brief history}

Spain has considerable experience in the implementation of toll motorway concessions. Since 1967, the Spanish central government has granted 31 motorway concessions. In 2008, a total of $2700 \mathrm{~km}$ had been awarded, and $2450 \mathrm{~km}$ of that total were already in operation.

There are three different periods in the history of toll motorway concessions in Spain (Vassallo and Sánchez, 2007): from 1967 to 1975, from 1976 to 1995, and from 1996 until 2007. From 1967 to 1975,15 motorway stretches were awarded, which account for almost $50 \%$ of the concessions granted in Spain up to 2007. The first set of toll motorway concessions were awarded through specific legislation approved by the government for each concession. The toll motorway regulation became much more stable in 1972 when the Toll Motorway Concession Law (Ley 8/1972 de Autopistas en Regimen de Concesión) was passed by the Spanish Parliament.

The second period lasted from 1976 to 1995 . During this period, mostly with a government under the Socialist Party, infrastructure funding policy in Spain changed radically. Instead of toll motorways, the government opted for modernising the Spanish road network by widening and upgrading the most important roads, turning them into double-track fast lanes free of charge (called autovias in Spanish) with quality standards below those for toll motorways.

The third period began in 1996 and continued to 2007. In 1996, the conservative Popular Party took office in Spain and the need to contain Spain's public deficit was the most difficult challenge facing the new government. This was the main reason why the new government decided to implement once again the policy of offering concessions so as to encourage the participation of the private sector in the financing of new transportation infrastructure. From 1996 to 2007, 16 toll highways concessions - 15 of them were already in operation - have been awarded by the central government of Spain through this approach, making a total of $1003 \mathrm{~km}$. This new trend towards private funding was reinforced by a new Public Works Concession Law, passed in 
Transport

Volume 165 Issue TR2
Traffic uncertainty in toll motorway

concessions in Spain

Baeza and Vassallo
2003, which extended and updated the old Toll Motorway Concession Law passed in 1972.

\subsection{Main features of concession contracts in Spain}

Even though there are some differences between the concessions awarded in the first period (1967-1975) and the concessions awarded in the third period (1996-2007), toll motorway concessions in Spain have had the same distinctive features over the years. Toll motorway concessions in Spain are always greenfield projects, which means that the motorways are always new; or, in other words, not built over the alignment of a previously existing road. The most important risks of the concession (land acquisition, construction, operation and traffic demand) are allocated to the concessionaire.

Central government is required to conduct a feasibility study to decide whether the project is suitable to be financed and operated through a concession contract or not. The feasibility study requires the government to carry out traffic forecasts to assess the feasibility of the concession. This feasibility study is crucial to determine whether the concession would require public subsidies to be viable. The traffic estimates necessary for this study are conducted by the Planning Department of the Secretary of Public Works. Once the government has decided to undertake the project through a concession, the traffic forecasts conducted by the government are submitted to the bidders, although the bidders have total freedom to include their own estimates in their bids.

Unlike other long-term infrastructure contracts in the world (e.g. design-build-finance-operate (DBFO) contracts in the UK or Portugal), toll concession contracts in Spain are awarded on the basis of the 'open procedure', instead of the 'negotiated procedure'. The 'open procedure' is based on granting the concession to the best offer in terms of a set of criteria predefined by the government in the bidding terms. Before the tender takes place, the government writes a standard contract, which will determine the future relationship with the eventual concessionaire (Sánchez and Gago, 2010).

Toll caps are established in toll concession contracts in Spain for every kind of vehicle. According to the contract, the tolls are updated every year in line with inflation. In the year 2000, a provision was introduced in order to allow slight modifications of the tolls rates if traffic became lower or higher than expected. The influence of this provision in the toll levels and consequently on the traffic levels is however negligible (Bel and Fagueda, 2005).

\section{Case study of toll motorway concessions in Spain}

The purpose of this section is to analyse the degree of inaccuracy of the traffic estimates conducted for toll motorway concessions awarded by the central government of Spain during the first 5 years of operation, which is usually called 'ramp-up period'.

\subsection{Methodology for the analysis of the inaccuracy of traffic estimates in Spain}

The methodology used in this research was based on comparing the actual traffic with the traffic estimates for toll motorway concessions in Spain. To that end, an indicator is defined that is called the 'annual traffic deviation' (see Equation 1). This indicator shows the inaccuracy of the estimates, whether over or under, of actual traffic in year $t$ compared to the forecasted traffic in year $t$. This indicator is calculated according to Equation 1.

$$
\text { 1. } A D_{t}^{j}=\frac{R Y_{t}^{j}-F Y_{t}^{j}}{F Y_{t}^{j}} \times 100=\left(\frac{R Y_{t}^{j}}{F Y_{t}^{j}}-1\right) \times 100
$$

where $A D_{t}^{j}$ is the annual traffic deviation for year $t$ and concession $j ; R Y_{t}^{j}$ is the real traffic (annual average daily traffic in year $t$ for concession $j$ ); $F Y_{t}^{j}$ is the forecasted traffic (annual average daily traffic in year $t$ for concession $j$ ).

If $A D_{t}^{j}>0$, traffic predictions were underestimated whereas if $A D_{t}^{j}<0$, traffic predictions were overestimated. In the present research, this indicator was calculated for the estimates provided by the concessionaire in the tender and the estimates conducted by the central government in the original feasibility study.

\subsection{Data}

The present database included only the concessions awarded during the third period, from 1996 to 2007. The concessions awarded in the first period (from 1967 to 1975) were not analysed because only a few estimates were available for those toll concessions and they were awarded under a different legislation and socio-economic framework. The toll motorway concessions included in the present database have similar characteristics: all of them are greenfield projects, all of them are located in Spain, all of them are regulated by the same legislation, and all of them were awarded in recent years. The main difference across the concessions is related to the availability of transport alternatives since some concessions compete with free motorways whereas others compete with free roads or toll motorways. The gross domestic product (GDP) and the consumer price index (CPI) growth in Spain remained quite stable over the period of analysis, with the exception of the year 2008 in which the economic crisis prompted a substantial change in their development (see Table 1).

The annual average daily traffic (AADT) for each concession was obtained from the databases that are published every year by the Secretary of Public Works (Ministerio de Fomento) of the government of Spain. The last issue of this publication includes data up to 2008 .

Obtaining the information of the estimates by the central government and the concessionaire was quite a challenge as this information is not public in Spain. The information regarding the government's estimates was made available by the Planning 


\begin{tabular}{|c|c|c|c|c|c|c|c|c|c|c|}
\hline \multirow[t]{2}{*}{ Toll highway concessions } & \multirow{2}{*}{$\begin{array}{c}\text { First year } \\
\text { of } \\
\text { operation }\end{array}$} & \multicolumn{9}{|c|}{ Annual growth: \% } \\
\hline & & $\begin{array}{c}1999 \\
-00\end{array}$ & $\begin{array}{c}2000 \\
-01\end{array}$ & $\begin{array}{c}2001 \\
-02\end{array}$ & $\begin{array}{c}2002 \\
-03\end{array}$ & $\begin{array}{c}2003 \\
-04\end{array}$ & $\begin{array}{c}2004 \\
-05\end{array}$ & $\begin{array}{c}2005 \\
-06\end{array}$ & $\begin{array}{c}2006 \\
-07\end{array}$ & $\begin{array}{c}2007 \\
-08\end{array}$ \\
\hline Annual GDP growth in real terms & & $5 \cdot 13$ & $4 \cdot 25$ & $3 \cdot 48$ & $4 \cdot 27$ & $4 \cdot 27$ & 4.55 & $4 \cdot 64$ & 4.09 & -0.67 \\
\hline Annual CPI growth & & $3 \cdot 40$ & $3 \cdot 60$ & $3 \cdot 50$ & 3.00 & 3.00 & $3 \cdot 40$ & $3 \cdot 50$ & $2 \cdot 80$ & $4 \cdot 10$ \\
\hline Málaga-Estepona-Guadiaro & 1999 & $36 \cdot 93$ & $19 \cdot 77$ & $16 \cdot 21$ & $18 \cdot 86$ & 8.00 & $6 \cdot 71$ & $4 \cdot 27$ & $3 \cdot 39$ & -8.61 \\
\hline Alicante-Cartagena & 2001 & & & 9.09 & $21 \cdot 00$ & $12 \cdot 51$ & $5 \cdot 78$ & $4 \cdot 24$ & $3 \cdot 56$ & $-9 \cdot 74$ \\
\hline Ávila-Villacastín & 2002 & & & & $16 \cdot 28$ & $11 \cdot 67$ & $2 \cdot 37$ & $4 \cdot 17$ & $12 \cdot 24$ & 0.67 \\
\hline Santiago-Alto de Santo Domingo & 2003 & & & & & $20 \cdot 89$ & 1.81 & 8.66 & $13 \cdot 45$ & 3.65 \\
\hline Segovia-El Espinar & 2003 & & & & & -0.77 & $5 \cdot 16$ & $10 \cdot 55$ & $11 \cdot 42$ & $-3 \cdot 42$ \\
\hline León-Astorga & 2003 & & & & & $-12 \cdot 24$ & $5 \cdot 17$ & $8 \cdot 29$ & $19 \cdot 98$ & $4 \cdot 37$ \\
\hline R-2 Madrid Guadalajara & 2003 & & & & & $23 \cdot 53$ & $24 \cdot 08$ & $23 \cdot 89$ & $16 \cdot 15$ & -3.99 \\
\hline R-3 Madrid Arganda & 2004 & & & & & & $28 \cdot 51$ & $19 \cdot 53$ & 0.58 & $-6 \cdot 39$ \\
\hline R-5 Madrid Navalcarnero & 2004 & & & & & & $15 \cdot 88$ & $28 \cdot 84$ & $16 \cdot 22$ & $-4 \cdot 68$ \\
\hline R-4 Madrid Ocaña & 2004 & & & & & & $5 \cdot 62$ & 36.09 & $23 \cdot 79$ & $-8 \cdot 52$ \\
\hline Eje aeropuerto & 2005 & & & & & & & $73 \cdot 33$ & $15 \cdot 75$ & $-6 \cdot 64$ \\
\hline Ocaña-La Roda & 2006 & & & & & & & & $9 \cdot 94$ & $3 \cdot 32$ \\
\hline Madrid-Toledo & 2006 & & & & & & & & $59 \cdot 10$ & $-13 \cdot 32$ \\
\hline Cartagena-Vera & 2007 & & & & & & & & & $8 \cdot 37$ \\
\hline Circunvalación de Alicante & 2007 & & & & & & & & & $18 \cdot 55$ \\
\hline
\end{tabular}

Table 1. Real traffic growth in toll highway concessions included in the sample

Department of the Secretary of Public Works. The estimates of the concessionaire, which are included in the financial plans submitted by the bidders in the tender, were provided by the Concession Unit of the Secretary of Public Works.

\subsection{Results}

Before implementing the methodology outlined earlier, it seems interesting to take a look at the evolution of traffic growth over the period of analysis, in comparison with the evolution of some macroeconomic indicators. To this end the annual traffic growth is compared with the annual GDP growth in real terms and the CPI indexes in Table 1. From the analysis of Table 1, two aspects are of note. First, the traffic growth from the first to the second year of operation was very large for most of the concessions (see the shaded cells in the Table 1); and second, traffic growth seems to be extremely sensitive to GDP growth. In other words, for most of the concessions, traffic grows more than the GDP in real terms when the economy is doing well. However, traffic decreases more than the GDP when the economy is doing poorly (note this effect in last column of the table).

Table 2 shows a summary of the traffic deviations $\left(A D_{t}^{j}\right)$ of the concessionaires' estimates, measured according to Equation 1, during the first 5 years of operation. For some concessions a track record of 5 years of operation is not available because those concessions started their operation phase recently. In spite of this, they have been included in the database to consider all the toll motorways in operation within the period of analysis in order to have a more complete sample. The table shows several trends related to the behaviour of the traffic deviations.

(a) Traffic levels were substantially overestimated by all the concessionaires during the years analysed. The only exception was the Málaga-Estepona-Guadiaro motorway where traffic predictions underestimated traffic for years 4 and 5 . The average overestimation for the first 2 years of operation was particularly high.

(b) On average, the accuracy of the estimates improved over time. The average overestimation for those concessions with a track record of 5 years (concessions 1 to 10) progressively improved from $-43 \cdot 6 \%$ in year 1 to $-27 \cdot 4 \%$ in year 5 .

(c) The trend described above changed in 2008 because of a severe recession (see the shaded cells in Table 2). For this year, the traffic estimates prove to be less accurate than the year before. The only exceptions to this rule are the motorways that in 2008 were in the first year of the ramp-up period (Cartagena-Vera and Circunvalación de Alicante).

(d) The toll motorways that compete directly with a free motorway (those rows printed in bold and italics in Table 2) show in general higher overestimation levels than the toll motorways that have other types of competition.

(e) Regarding the standard deviation of $A D_{t}^{j}$, it was found that in general this tended to increase over the years. This means that, even though the further into the future the year under discussion, the better on average is the initial prediction, 
whereas the further the year, the more different is the behaviour of the concessions in the sample.

In Table 3 the results obtained in the present study are compared with the results obtained by Bain (2009), who conducted a similar study using a worldwide database of toll road projects. The main differences between the two studies are listed here.

(a) The overestimation level in Spain is higher than the worldwide results obtained by Bain (Bel and Fagueda, 2005). One of the reasons for this difference could be that Bain's estimations are those approved by the banks at the financial close of the projects whereas the estimations that have been incorporated in the present research are those of the concessionaires at the tender stage. Unlike the general practice in many countries, in Spain the financial close always takes place after the contracts are awarded.

(b) The estimates' accuracy in Bain's study remained similar over the years whereas the results for Spain show a better accuracy over time. This may be caused by the fact that all the toll motorway concessions in Spain are greenfield projects, whereas not all the projects in Bain's database are necessarily greenfield. Moreover, all the toll motorways in Spain have at least a road alternative whereas this is not common in some toll roads programmes around the world (for instance in Latin American concessions).

(c) The standard deviation of the traffic deviations in the database used for the present study is lower than in Bain's database. This might be caused by the fact that the sample in Spain is quite homogeneous - projects with similar characteristics and the same legislation - whereas in Bain's worldwide database, projects are rather heterogeneous.

After comparing the present results with Bain's, the focus of the study moved on to consider the determining statistical significance of the two major trends that were observed in this research: (a) a bias towards overestimating traffic, and (b) the fact that concessions that have free parallel motorways competing with them show less accurate predictions. In order to evaluate the statistical significance of those trends, five regressions were calibrated - one for each year - according to Equation 2.

$$
A D_{t}^{j}=\alpha_{t}+\beta_{t} \cdot X^{j}+\varepsilon_{t}^{j}
$$

with $t=1$ to 5

$$
\begin{gathered}
X^{j}=1 \text { if concession } j \text { competes with a } \\
\text { free motorway }
\end{gathered}
$$

2. $X^{j}=0$ otherwise

where $X^{j}$ is the categorical variable reflecting the kind of competition for concession $j ; \alpha_{t}$ is the independent parameter of the regression for year $t ; \beta_{t}$ is the parameter of the categorical variable $X^{j}$ for the regression of year $t ; \varepsilon_{t}^{j}$ is the error for observation $j$ in the regression calibrated for year $t$.

The results of the regression are displayed in Table 4. All the regressions are significant at the $95 \%$ level of confidence since the probability of the F-statistic is always $<0.05$ (see last column of Table 4). Likewise, all the parameters of the calibrated regressions, with the only exception of $\alpha_{5}$, are significant at the $95 \%$ level of confidence since the probability of the $t$-statistic is $<0 \cdot 05$. Consequently, the results of the regression demonstrate that: $(a)$ there is a significant bias towards overestimating traffic; and $(b)$ the fact that the toll highway competes with a free motorway has significant influence in the level of overestimation.

Moreover, looking at the $\alpha_{t}$ and $\beta_{t}$ parameters across the different years, it can be seen that while the $\alpha_{t}$ parameter diminishes over the years from $-40 \cdot 2$ to $-14 \cdot 3 \%$, the $\beta_{t}$ parameters remain more or less around $-25 \%$. This means that the errors on the estimates corresponding to the first years of operation improve over the years whereas the errors on the estimates caused by the existence of a parallel motorway remain very much the same over the years.

Finally, a comparison was conducted between the inaccuracy of the concessionaires' estimates and the inaccuracy of the estimates conducted by central government. It should be noted that central government conducts its estimates within the framework of a feasibility study to determine whether the project is viable or not.

\begin{tabular}{lccccc}
\hline \multirow{2}{*}{ Years from opening } & \multicolumn{2}{c}{ Mean } & & \multicolumn{2}{c}{ Standard deviation } \\
\cline { 2 - 3 } \cline { 5 - 6 } & Bain's study & Spain study & & Bain's study & Spain study \\
\cline { 2 - 3 } & & & & 0.26 & 0.14 \\
Year 1 & -0.23 & -0.44 & & 0.26 & 0.14 \\
Year 2 & -0.22 & -0.40 & & 0.23 & 0.15 \\
Year 3 & -0.21 & -0.35 & & 0.22 & 0.18 \\
Year 4 & -0.20 & -0.29 & & 0.24 & 0.22 \\
Year 5 & -0.21 & -0.27 & & 0.25 & 0.25
\end{tabular}

Table 3. Comparison of the results with those obtained by Bain

(2009) 


\begin{tabular}{lccccc}
\hline Linear regression & Year 1 & Year 2 & Year 3 & Year 4 & Year 5 \\
\hline$\alpha_{\mathrm{t}}$ & -0.402 & -0.378 & -0.304 & -0.203 & -0.143 \\
& $(0.000)$ & $(0.000)$ & $(0.000)$ & $(0.010)$ & $(0.051)$ \\
Free motorway $\left(\beta_{\mathrm{t}}\right)$ & -0.256 & -0.215 & -0.253 & -0.267 & -0.326 \\
& $(0.002)$ & $(0.006)$ & $(0.016)$ & $(0.018)$ & $(0.011)$ \\
Observations & 15 & 15 & 13 & 11 & 10 \\
$R$-squared & 0.51 & 0.45 & 0.42 & 0.48 & 0.58 \\
$F$ & 13.65 & 10.47 & 8.12 & 8.27 & 10.84 \\
Significance $F$ & 0.003 & 0.006 & 0.016 & 0.018 & 0.011 \\
\hline
\end{tabular}

$p$-values of the $t$ statistic in parenthesis

Table 4. Calibration of the regression to calculate the influence

of competition from a free motorway

Once the tender is open, the government makes these estimates available to the bidders who also have total freedom to conduct their own estimates.

Unfortunately, the government was only able to make available the estimates for 10 out of the 15 concessions that were analysed in this research. This information, however, was enough to enable the comparison between the government's and the concessionaires' estimates to be carried out. Table 5 summarises the results.

The main result from Table 5 is that the estimates conducted by the government are not much more accurate than those of the concessionaires. On the one hand, the government overestimates traffic for almost all the concessions and years analysed. On the other hand, with few exceptions (such as the Cartagena-Vera and León Astorga highways) the estimates conducted by the government are quite similar to those of the concessionaires. For some concessions, the estimates by the central government are even slightly more optimistic than those of the concessionaires (see the cells shaded in Table 5). In spite of that, on average, the estimates by the central government are between 6.32 and $11.26 \%$ more accurate than those of the concessionaires (see the mean differences row on the bottom of Table 5).

\subsection{Consequences of traffic overestimation on social welfare}

Baeza (2008) shows that, unlike traffic, capital and operation costs are not substantially overestimated by toll motorway concessionaires in Spain. In addition, the financial terms of the loans have remained fairly stable over the period of analysis. Apart from traffic, the only cost item that has experienced substantial overestimation in some of the concession contracts is the land acquisition cost. As the financial balance of a concession contract depends substantially on the items referred to above, it is clear that traffic overestimation has played a crucial role in the financial problems of toll highway concessions in Spain.
As a consequence of that, the following question arises: how were the concessionaires able to survive with such low traffic levels? The answer to this question is that renegotiations of concession contracts in Spain have been too common. The aim of the renegotiations has mostly been to rebalance the economics of the concession.

The historical record of renegotiations of toll highway concessions in Spain is extensive. The concessions awarded between 1967 and 1975 have been renegotiated on average eight times each. A total of $24 \%$ of these renegotiations have concluded with extensions of the concessions duration beyond the original duration fixed by the contracts, and $50 \%$ of the renegotiations have concluded with toll modifications. Two of the most important concessions awarded during the first period (Tarragona-Valencia and Valencia-Alicante) ultimately had a real traffic flow that barely reached $50 \%$ of the predicted value throughout the life of the contract. The concessions were able to survive because their duration was almost doubled (Baeza, 2008).

The concessions awarded from 1996 to 2007 have scarcely been renegotiated, mostly because the contracts are still fairly recent. However, the concessionaires and the government were, at the time of writing, on their way to reaching an agreement to improve the poor financial performance of the concessions. In fact, the public budget for year 2010 included provisions to rebalance the economics of the concession contracts due to low traffic and high land acquisition costs. Consequently, the renegotiation of the concession contracts awarded from 1996 onwards seems to be already a matter of fact.

The consequences of these renegotiations are that, in the end, future users have to bear the burden - through longer contracts or higher tolls - caused by the poor traffic estimates conducted by the government, which are made even poorer by the concessionaire. From the global welfare perspective, renegotiations seem neutral at first glance since they entail a mere transfer of resources from the users to the private concessionaires. However, 


\begin{tabular}{|c|c|c|c|c|c|c|c|}
\hline \multirow[t]{2}{*}{$j$} & \multirow[t]{2}{*}{ Motorway } & \multirow[t]{2}{*}{ Estimates } & \multicolumn{5}{|c|}{ Traffic deviations $A D_{t}^{j}: \%$} \\
\hline & & & 1 & 2 & 3 & 4 & 5 \\
\hline \multirow[t]{2}{*}{2} & \multirow[t]{2}{*}{ Alicante-Cartagena } & Government & $-23 \cdot 56$ & $-22 \cdot 70$ & -13.90 & $-7 \cdot 92$ & $-2 \cdot 84$ \\
\hline & & Concessionaire & $-23 \cdot 83$ & $-21 \cdot 36$ & -9.94 & $-4 \cdot 10$ & -3.98 \\
\hline \multirow[t]{2}{*}{4} & \multirow[t]{2}{*}{ Santiago-Alto de Santo Domingo } & Government & $-38 \cdot 13$ & $-27 \cdot 38$ & $-28 \cdot 21$ & $-24 \cdot 27$ & $-16 \cdot 60$ \\
\hline & & Concessionaire & $-43 \cdot 37$ & $-33 \cdot 02$ & $-34 \cdot 10$ & $-31 \cdot 80$ & $-25 \cdot 61$ \\
\hline \multirow[t]{2}{*}{6} & \multirow[t]{2}{*}{ León-Astorga } & Government & 4.71 & $-12 \cdot 83$ & $-12 \cdot 80$ & -9.97 & $3 \cdot 20$ \\
\hline & & Concessionaire & $-28 \cdot 12$ & $-44 \cdot 04$ & $-45 \cdot 61$ & $-45 \cdot 45$ & $-36 \cdot 94$ \\
\hline \multirow[t]{2}{*}{7} & \multirow[t]{2}{*}{ R-2 Madrid Guadalajara } & Government & $-50 \cdot 86$ & $-41 \cdot 64$ & $-32 \cdot 00$ & $-20 \cdot 90$ & $-13 \cdot 74$ \\
\hline & & Concessionaire & $-62 \cdot 68$ & $-57 \cdot 76$ & $-58 \cdot 16$ & $-47 \cdot 26$ & $-42 \cdot 75$ \\
\hline \multirow[t]{2}{*}{8} & \multirow[t]{2}{*}{ R-3 Madrid Arganda } & Government & $-56 \cdot 59$ & $-47 \cdot 65$ & -41.04 & -43.95 & $-50 \cdot 25$ \\
\hline & & Concessionaire & $-56 \cdot 55$ & $-47 \cdot 43$ & $-40 \cdot 83$ & $-43 \cdot 96$ & $-50 \cdot 61$ \\
\hline \multirow[t]{2}{*}{9} & \multirow[t]{2}{*}{ R-5 Madrid Navalcarnero } & Government & $-61 \cdot 74$ & $-57 \cdot 28$ & $-48 \cdot 18$ & $-43 \cdot 29$ & $-49 \cdot 10$ \\
\hline & & Concessionaire & $-58 \cdot 49$ & $-55 \cdot 49$ & $-46 \cdot 94$ & $-42 \cdot 94$ & $-49 \cdot 68$ \\
\hline \multirow[t]{2}{*}{10} & \multirow[t]{2}{*}{ R-4 Madrid Ocaña } & Government & $-58 \cdot 80$ & $-58 \cdot 42$ & $-46 \cdot 39$ & $-37 \cdot 58$ & $-46 \cdot 27$ \\
\hline & & Concessionaire & $-56 \cdot 15$ & $-56 \cdot 57$ & $-44 \cdot 60$ & $-35 \cdot 70$ & $-44 \cdot 86$ \\
\hline \multirow[t]{2}{*}{11} & \multirow[t]{2}{*}{ Eje aeropuerto } & Government & $-71 \cdot 55$ & $-52 \cdot 32$ & $-49 \cdot 89$ & $-51 \cdot 45$ & - \\
\hline & & Concessionaire & -78.59 & $-64 \cdot 51$ & $-60 \cdot 73$ & $-64 \cdot 95$ & - \\
\hline \multirow[t]{2}{*}{12} & \multirow[t]{2}{*}{ Ocaña-La Roda } & Government & $-47 \cdot 58$ & $-47 \cdot 20$ & $-50 \cdot 02$ & - & - \\
\hline & & Concessionaire & $-48 \cdot 68$ & $-55 \cdot 44$ & $-56 \cdot 29$ & - & - \\
\hline \multirow[t]{2}{*}{14} & \multirow[t]{2}{*}{ Cartagena-Vera } & Government & $-46 \cdot 72$ & -48.06 & - & - & - \\
\hline & & Concessionaire & $-69 \cdot 67$ & $-64 \cdot 61$ & - & & \\
\hline \multirow{2}{*}{\multicolumn{2}{|c|}{$\begin{array}{l}\text { Mean motorways: } 2,4,6,7,8,9,10,11 \text {, } \\
12,14\end{array}$}} & Government & $-45 \cdot 08$ & $-41 \cdot 55$ & - & - & - \\
\hline & & Concessionaire & $-52 \cdot 61$ & $-50 \cdot 02$ & - & - & - \\
\hline \multirow{3}{*}{\multicolumn{2}{|c|}{$\begin{array}{l}\text { Mean differences } \\
\text { Mean motorways: } 2,4,6,7,8,9,10\end{array}$}} & $\mathrm{G}-\mathrm{C}$ & $7 \cdot 53$ & 8.48 & - & - & - \\
\hline & & Government & $-40 \cdot 71$ & $-38 \cdot 27$ & $-31 \cdot 79$ & $-26 \cdot 84$ & -25.08 \\
\hline & & Concessionaire & $-47 \cdot 03$ & $-45 \cdot 10$ & -40.03 & $-35 \cdot 89$ & $-36 \cdot 35$ \\
\hline \multirow{5}{*}{\multicolumn{2}{|c|}{$\begin{array}{l}\text { Mean differences } \\
\text { Standard deviation motorways: } 2,4,6,7,8 \text {, } \\
9,10,11,12,14 \\
\text { Standard deviation motorways: } 2,4,6,7,8 \text {, } \\
9,10\end{array}$}} & $\mathrm{G}-\mathrm{C}$ & $6 \cdot 32$ & $6 \cdot 83$ & $8 \cdot 24$ & $9 \cdot 05$ & $11 \cdot 26$ \\
\hline & & Government & 21.94 & $15 \cdot 42$ & - & - & - \\
\hline & & Concessionaire & $17 \cdot 19$ & $13 \cdot 90$ & - & - & - \\
\hline & & Government & $24 \cdot 11$ & $17 \cdot 68$ & $14 \cdot 50$ & $15 \cdot 07$ & 22.93 \\
\hline & & Concessionaire & $15 \cdot 60$ & $13 \cdot 64$ & $15 \cdot 11$ & $15 \cdot 07$ & $16 \cdot 62$ \\
\hline \multicolumn{8}{|c|}{$\begin{array}{l}\text { Table 5. Comparison between the estimates of the central } \\
\text { government and the concessionaire }\end{array}$} \\
\hline
\end{tabular}

the behaviour described above may prevent companies which are not familiar with how things work in Spain from participating in the tender, which reduces competition and, therefore, the ultimate efficiency.

\section{Conclusions}

From the analysis conducted for this paper the following conclusions are drawn.

(a) The traffic estimates for toll motorway concessions in Spain show a significant bias towards overestimation. This bias is even larger than the bias obtained by Bain (2009) for a worldwide database. Even though the estimates conducted by the government are slightly more accurate than those of the concessionaires, the government still shows a consistent trend towards overestimating traffic.

(b) For toll motorway concessions in Spain, the longer into the future the year for which estimates were made, the better the traffic predictions are; or, in other words, traffic predictions seem to be less accurate for the first years of operation. This fact may be caused by the difficulty in knowing the users' behaviour when a greenfield toll motorway is opened.

(c) The existence of a competitive free motorway in the corridor has a significant influence on the level of traffic overestimation. The toll motorway concessions that have a free motorway competing with them have overestimation levels around $25 \%$ greater than the toll motorways which have other kinds of competition (free road or toll motorway). 
Transport

Volume 165 Issue TR2
Traffic uncertainty in toll motorway

concessions in Spain

Baeza and Vassallo (d) The financial problems caused by a shortage of traffic have been traditionally solved in Spain through future renegotiations of the concession contracts that ended up with extensions of the concession terms or tolls modifications.

On the basis of the conclusions listed above, it appears that, even though correctly forecasting traffic is quite an issue for toll motorways, the consistent and significant bias towards overestimating traffic in Spain seems to be explained by the strategic behaviour of the government and the concessionaire rather than by modelling errors.

\section{Acknowledgements}

The authors would like to acknowledge the Toll Motorway Concession and Planning Departments of the Secretary of Public Works in Spain (Ministerio de Fomento) for providing access to all the information regarding the financial plans of the concessionaires available for toll motorway concessions in Spain. Without this help, this research would not have been possible.

\section{REFERENCES}

Athias L and Nuñez A (2008) Winner's curse in toll road concessions. Economic Letters 101(3): 172-174.

Baeza MA (2008) Planificación económico-financiera de las concesiones de autopistas de peaje. Un estudio empírico del caso español. Doctoral thesis, University of Grenada, Spain (in Spanish).

Bain R (2009) Error and optimism bias in toll road traffic forecasts. Transportation 36(5): 469-482.

Bain R and Plantagie M (2004) Traffic Forecasting Risk: Study Update 2004. Standard \& Poor's, London, UK.

Bain R and Polakovic L (2005) Traffic forecasting risk study update 2005 through ramp-up and beyond. Proceedings of the European Transport Conference, Strasbourg, France (CD-ROM).

Bel $\mathrm{G}$ and Fagueda X (2005) Is a mixed funding model for the highway network sustainable over time? In Procuring and Financing Motorways in Europe (Ragazzi G and Rothengatter W (eds)). Elsevier, Amsterdam, the Netherlands, pp. 195 211.

Capen E, Clapp R and Campbell W (2001) Competitive bidding in high-risk situations. Journal of Petroleum Technology 23(6): 641-653.

De Jong G, Daly A, Pieters M et al. (2007) Uncertainty in traffic forecasts: literature review and new results for The Netherlands. Transportation 34(4): 375-395.

Debande O (2005) Private financing of transport infrastructure: an assessment of the UK experience. Journal of Transport Economics and Policy 36(3): 355-387.

Fayard A and Bousquet F (1998) Pragmatic approach to finance infrastructure. Analysis of French experience with motorway concessions. Transportation Research Record 1649: 9-16.

Flyvbjerg B, Bruzelius N and Rothengatter W (2003) Megaprojects and Risk: An Anatomy of Ambition. Cambridge University Press, Cambridge, UK.
Flyvbjerg B, Skamris MK and Buhl SL (2005) How (in)accurate are demand forecasts in public works projects? The case of transportation. Journal of the American Planning Association 71(2): 131-146.

Foote J (2006) Analysis of the Public Policy Aspects of the Chicago Skyway Concession. Working Paper, Center for Business and Government, John F. Kennedy School of Government, Harvard University, Cambridge, Massachusetts, USA.

Gómez-Lobo A and Hinojosa S (2000) Broads Roads in a Thin Country: Infrastructure Concessions in Chile. The World Bank, Washington DC, USA, Research Paper 2279.

Guasch JL, Laffont JJ and Straub S (2003) Renegotiation of Concession Contracts in Latin America. The World Bank, Washington DC, USA, Policy Research Working Paper 3011.

Izquierdo R and Vassallo JM (2004) Nuevos sistemas de gestión y financiación de infraestructuras de transporte. Colegio de Ingenieros de Caminos, Canales y Puertos, Madrid, Spain, Colección SEINOR no. 35 (in Spanish).

OECD (Organisation for Economic Co-operation and Development) (2008) Transport Infrastructure Investment: Options for Efficiency. International Transport Forum, Paris, France.

Sánchez A and Gago P (2010) Transaction costs in transport public-private partnerships: comparing procurement procedures. Transport Reviews 30(3): 389-406.

Vassallo JM (2004) Short-term infrastructure concessions: conceptual approach and recent applications in Spain. Public Works Management and Policy 8(4): 261-270.

Vassallo JM and Baeza MA (2007) Why Traffic Forecasts in PPP Contracts are Often Overestimated. European Investment Bank, Luxembourg, Research Paper.

Vassallo JM and Sánchez A (2007) Subordinated public participation loans for financing toll highway concessions in Spain. Transportation Research Record 1996: 1-9.

\section{WHAT DO YOU THINK?}

To discuss this paper, please email up to 500 words to the editor at journals@ice.org.uk. Your contribution will be forwarded to the author(s) for a reply and, if considered appropriate by the editorial panel, will be published as a discussion in a future issue of the journal.

Proceedings journals rely entirely on contributions sent in by civil engineering professionals, academics and students. Papers should be 2000-5000 words long (briefing papers should be 1000-2000 words long), with adequate illustrations and references. You can submit your paper online via www.icevirtuallibrary.com/content/journals, where you will also find detailed author guidelines. 